\title{
IMPLEMENTASI KEBIJAKAN QANUN KOTA LHOKSEUMAWE NOMOR 9 TAHUN 2015 TENTANG PENGELOLAAN SAMPAH OLEH DINAS LINGKUNGAN HIDUP KOTA LHOKSEUMAWE
}

\author{
Ana Zahara, Nirzalin, Muhammad Bin Abubakar \\ Prodi Magister Administrasi Publik, Fakultas Ilmu Sosial dan Ilmu Politik Universitas Malikussaleh \\ Jln. Tengku Chik diTiro, NO. 26, Lancang Garam, Lhokseumawe-24351 \\ Korespondensi: e-mail: nirzalin@unimal ac.id
}

\begin{abstract}
Penelitian ini mengkaji tentang Implementasi Kebijakan Qanun Kota Lhokseumawe Nomor 9 Tahun 2015 Tentang Pengelolaan Sampah Oleh Dinas Lingkungan Hidup Kota Lhokseumawe.Pertimbangan dipilihnya Lokasi penelitian di Kota Lhokseumawe karena adanya fenomena bahwa saat ini volume sampah yang timbul di Kota Lhokseumawe setiap harinya terus meningkat.Tujuan penelitian ini untuk mendeskripsikan Implementasi Kebijakan Qanun Kota Lhokseumawe Nomor 9 Tahun 2015 Tentang Pengelolaan Sampah Oleh Dinas Lingkungan Hidup Kota Lhokseumawe.Pendekatan yang digunakan dalam penelitian ini adalah pendekatan penelitian kualitatif.Teknik pengumpulan data yang digunakan adalah Observasi, wawancara dan dokumentasi. Berdasarkan hasil penelitian yang dilakukan, dapat disimpulkan bahwa Pengelolaan sampah di Kota Lhokseumawe belum maksimal apabila dilihat pada Qanun Kota Lhokseumawe Nomor 9 Tahun 2015 tentang Pengelolaan sampah, yang didasarkan pada model Implementasi menurut George Edward III yakni Komunikasi, Sumber Daya, Disposisi dan Struktur Birokrasi.Pengelolaan sampah di Kota Lhokseumawe masih perlu adanya pembenahan karena masih dilakukan dengan sistem konvensional yaitu kumpul, angkut dan buang. Selain itu faktor pengahambat Implementasi Kebijakan Qanun Kota Lhokseumawe Tentang Pengelolaan Sampah Oleh Dinas Lingkungan Hidup Kota Lhokseumaweantara lain perlu sosialisasi dan pelatihan tentang tata cara pengelolaan sampah kepada masyarakat, terbatasnya sarana dan prasarana yang dimiliki Dinas Lingkungan Hidup baik armada pengangkut sampah maupun mesin pengelolah sampah yang tidak bisa difungsikan, belum adanya SOP mengenai kegiatan petugas lapangan pengelolah sampah, kurangnya perhatian pemeritah terhadap kesejahteraan petugas lapangan dan aspek eksternal kurangnya kesadaran dan partisipasi dari masyarakat Kota Lhokseumawe dalam pengelolaan sampah.

Keywords: Implementasi,Kebijakan,Qanun Kota Lhokseumawe Nomor 9 Tahun 2015

Tentang Pengelolaan Sampah, Dinas Lingkungan Hidup
\end{abstract}

\section{Pendahuluan}

Permasalahan lingkungan merupakan masalah yang selalu mencuat akhir-akhir ini dan menjadi beban serta permasalahan serius di Kabupaten/Kota, hal tersebut muncul disebabkan kerena sampah khususnya sampah perkotaan tidak tertangani dengan baik.Masalah yang timbul adalah mengakibatkan lingkungan perkotaan menjadi lingkungan yang kurang bersih dan kurang sehat.

Pertambahan penduduk dan perubahan pola konsumsi masyarakat menimbulkan bertambahnya volume jenis, dan karakteristik sampah yang semakin beragam, Sampah yang telah dihasilkan menjadi permasalahan lingkungan yang harus ditanggulangi oleh stakeholdersyakni pemerintah, pihak swasta dan juga masyarakat. 
Pengelolaan sampah merupakan public service yang akan memberikan manfaat bagi setiap manusia, walaupun kehadiran sampah akan menimbulkan public cost yang sangat besar dalam penanganannya, kenyataan yang terjadi di kota-kota Indonesia pengelolaan sampah hanya sekedar mengangkut dan membuang begitu saja tanpa adanya prosese pendaur ulangan sampah. Karena sampah menurunkan nilai estetika suatu wilayah apabila penanganan sampah yang buruk dan sampah juga bisa menyebabkan banjir pada musim hujan apabila sampah dibuang sembarangan kesaluran air.

Dalam Qanun Kota Lhokseumawe Nomor 9 Tahun 2015 dalam Pasal 3 menjelaskan pengelolaan sampah bertujuan untuk meningkatkan standar kesehatan masyarakat, kualitas dan kebersihan lingkungan, serta dapat menjadikan sampah sebagai sumber daya yang bernilai ekonomi (Pasal 3 Qanun Kota Lhokseumawe 9/2015).

Pengelolaan sampah di Lhokseumawe masih menggunakan sistem konvensional yakni kumpul, angkut, dan buang. Dengan penyelesaian akhir di Tempat Pembuangan Akhir (TPA) Alue Lim yang masih open dumping yaitu suatu sistem pembuangan sampah yang dilakukan secara terbuka, Sistem ini masih terus digunakan karena masyarakat belum mengetahui cara pengelolaan sampah dengan baik. sehingga menimbulkan masalah pada lahan penimbunan terbuka, berbagai hama dan kuman penyebab penyakit dapat berkembang biak.

Selain itu, tempat sampah yang sudah ada ditempat umum juga tidak berfungsu secara efektif, terlihat di TPS (Tempat Pembuangan Sementara) yang tersebar di beberapa titik di Kota Lhokseumawe hanya sebagai tempat pembuangan akhir bagi masyarakat. Di TPA (Tempat Pembuangan Akhir) juga masih menjadi masalah, ini dibuktikan dari tahun ke tahun tidak ada perubahan metode pengelolaan sampah yang baik.

Berbagai upaya dilakukan untuk menangani pengelolaan sampah, namun upaya tersebut kerap mengalami kendala, Meningkatnya jumlah penduduk dan aktivitas yang dilakukan untuk meningkatkan pertumbuhan ekonomi akan berpengaruh terhadap meningkatnya volume sampah di Kota Lhokseumawe

Apabila masalah ini tidak dilakukan perubahan dalam penanganannya, baik teknis, maupun kebijakan politis, dalam waktu dekat diprediksi dapat mengakibatkan terjadinya pencemaran lingkungan yang cukup signifikan di seluruh wilayah, baik langsung maupun tidak langsung, oleh karena itu aktifitas pengelolaan sampah juga harus ditingkatkan.

Tabel 1.1. Jumlah Volume Sampah Kota Lhokseumawe 


\begin{tabular}{|c|c|c|}
\hline Tahun & Volume Produksi & Volume Ditangani \\
\hline 2018 & $95.174 \mathrm{M}^{3}$ & $72.810 \mathrm{M}^{3}$ \\
\hline 2019 & $97.815 \mathrm{M}^{3}$ & $72.778 \mathrm{M}^{3}$ \\
\hline 2020 & $98.379 \mathrm{M}^{3}$ & $73.014 \mathrm{M}^{3}$ \\
\hline
\end{tabular}

Dari tahun 2018 sampai 2020 rata-rata produksi sampah di Kota Lhokseumawe selalu meningkat, setiap hari volume sampah di Kota Lhokseumawe meningkat 0,13\% .Namun pemerintah belum mampu menanganinya dengan baik.

Berdasarkan realita tersebut, peneliti tertarik mengkaji tentang "Implementasi Kebijakan Qanun Kota Lhokseumawe Nomor 9 Tahun 2015 Tentang Pengelolaan Sampah Oleh Dinas Lingkungan Hidup Kota Lhokseumawe.”.Utamanya untuk mengetahui dan memahami bagaimana Dinas Lingkungan Hidup dalam mengelolah samapah.

\section{Rumusan Masalah}

1. BagaimanaImplementasi Kebijakan Qanun Kota Lhokseumawe Nomor 9 Tahun 2015 Tentang Pengelolaan Sampah Oleh Dinas Lingkungan Hidup Kota Lhokseumawe?

2. Apa yang menghambat Implementasi Kebijakan Qanun Kota Lhokseumawe Nomor 9 Tahun 2015 Tentang Pengelolaan Sampah Oleh Dinas Lingkungan Hidup Kota Lhokseumawe?

\section{Fokus Penelitian}

1. Implementasi Kebijakan Qanun Kota Lhokseumawe Nomor 9 Tahun 2015 Tentang Pengelolaan Sampah Dengan memfokuskan implementasi sesuai indikator implementasi menurut George Edward III yaitu, Komunikasi, Ketersediaan sumber daya, Disposisi dan Struktur Birokrasi

2. Hambatan ImplementasiKebijakan Qanun Kota Lhokseumawe Nomor 9 Tahun 2015 Tentang Pengelolaan Sampah Oleh Dinas Lingkungan Hidup Kota Lhokseumawe. Dengan memfokuskan secara internal dan eksternal yang menghalangi pengelolaan sampah.

\section{Kajian Terdahulu: Landasan Teoritis}

Teori merupakan landasan yang teramat penting dalam memahami, menafsirkan dan memaknai data, oleh karena itu untuk memudahkan penafsira data dalam penelitian ini, maka penulis menggunakan beberapa teori sebagai berikut :

\section{Administrasi Publik}




\section{Pengertian Kebijakan Publik}

Menurut Miftah Toha (2008:103) "Kebijakan merupakan praktik sosial, ia bukan event yang tunggal atau terisolir. Dengan demikian sesuatu yang dihasilkan pemerintah berasal dari segala kebijakan dalam masyarakat dan dipergunakan pula untuk kepentingan masyarakat”.

Menurut Thomas R.Dye dalam Miftah Toha (2008: 107) "Kebijakan Publik adalah apa pun yang dipilih oleh pemerintah untuk dilakukan ataupun untuk tidak dilakukan (whatever government choose to do or not to do )". Dalam pengertian seperti ini, maka pusat perhatian dari Kebijakan Publik tidak hanya pada apa saja yang dilajukan oleh pemerintah, melainkan termasuk apa saja yang tidak dilakukan oleh pemerintah.

Menurut Riant Nugroho (2011:142) “Kebijakan Publik adalah jalan yang dicapai untuk tujuan bersama yang dicita-citakan". Jika cita-cita bangsa Indonesia adalah mencapai masyarakata yang adil dan makmur berdasarkan pancasila Ketuhanan, Persatuan, Demokrasi, dan Keadilan dan UUD 1945 (Negara Kesatuan Republik Indonesia yang berdasarkan hukum dan tidak semata-mata kekuasaan), kebijakan publik adalah selurug prasarana (jalan,jembatan,dan sebagainya) dan sarana (monil, bahan bakar, dan sebagainya) untuk mencapai “tempat tujuan” tersebut.

Menurut Friedrich dalam Widodo (2009:13) mengertikan kebijakan sebagai "suatu tindakan yang mengarah pada tujuan yng diusulkan oleh seseorang, kelompok atau pemerintah dalam lingkungan tertentu sehubungn dengan adanya hambatan-hambatan tertentu seraya mencari peluangpeluang untuk mencapai tujuan atau mewujudkan sasaran yang diinginkan”.

Kebijakan publik adalah serangkaian tindakan yang dilakuknan atau tidak dilakukan oleh pemerintah yang berorientasi pada tujuan tertentu guna memecahkan masalah-masalah publik atau demi kepentingan publik.Kebijakan untuk melakukan sesuatu biasanya tertuang dalam ketentuanketentuan peraturan perundang- undangan yang dibuat pemerintah sehingga memiliki sifat yang mengikat dan memaksa.

\section{Tahapan Kebijakan Publik}

Menurut pandangan Repley dalam Subarsono(2011:11),bahwa tahapan kebijakan publik teridir dari :

a. Penyusunan Agenda

Agenda setting adalah sebuah fase dan proses yang sangat strategis dalam realitas kebijakan publik. Dalam proses inilah terdapat ruang untuk memaknai apa yang disebut sebagi masalah publik dan prioritas dalam agenda publik dipertarungkan. Jika sebiah isu berhasil mendapatkan status sebagau masalah publik, dan mendapat prioritas dalam agenda publik,

b. Formulasi Kebijakan 
Masalah yang sudah masuk dalam agenda kebijakan kemudian dibahas oleh para pembuat kebijkan.dalam tahap perumusan kebijakan masing-amsing alternatif bersaing untuk dapat dipilih sebagai kebijakan yang diambil untuk memecahkan masalah.

c. Legitimasi Kebijakan

Tujuan legtimasi adalah untuk memberika otorisasi pada proses dasar pemerintahan. Jika tindakan legitimasi suatu masyarakat diatur oleh kedaulatan rakyat, warga negara mengikuti arahan pemerintah

d. Implementasi Kebijakan

Keputusan kebijakan yang telah diambil sebagai alternatif pemecahan masalah harus diimplementasikan, yakni dilaksanakn oleh badan-badan administrasi maupun agen-agen pemerintah ditingkat bawah.

e. Evaluasi Kebijakan

Evaluasi dipandang sebagai suatu kegatan fungsional, artinya evaluasi kebijakan tidak hanya dilakukan pada tahap akhir saja, melainkan dilakukan dalam seluruh proses kebijakan

\section{Implementasi Kebijakan Publik}

Beberapa teori tentang implementasi program atau kebijakan imlementasi program atau kebijakan merupakan salah satu tahap yang penting dalam proses kebijakan publik suatu program kebijakan dapat di implementasikan agar dapat mewujudkan dampak dan tujuan yang diinginkan.

Teori Implementasi menurut George Edward III dalam Widodo (2010:97) menjelaskan bahwa terdapat empat variable kritis dalam implementasi kebijakan publik, Variabel-variabel tersebut saling berkaitan satu sama lain untuk mencapai tujuan implementasi kebijakan :

a. Komunikasi

Menurut Edward III dalam Widodo ( 2010:97), Komunikasi diartikan sebagai "Proses penyampaian informasi komunikator kepada komunikan”. Informasi mengenai kebijakan publik perlu disampaikan kepada pelaku kebijakan agar para pelaku kebijakan dapat mengetahui apa yang harus mereka persiapkan dan lakukan untuk menjalankan kebijakan tersebut sehingga tujuan dan sasaran kebijakan dapat dicapai sesuai dengan yang diharapkan.

Menurut Edward III dalam Widodo (2010:97), komunikasi kebijakan memiliki beberapa dimensi antara lain:

1) Dimensi transmisi

2) Dimensi Kejelasan 


\section{3) Dimensi Konsistensi}

b. Sumber Daya

Menurut Edward III dalam widodo (2010:98) mengemukakan bahwa faktor sumber daya mempunyai peranan penting dalam implemnetasi kebijakan, karena bagaimanapun dibutuhkan kejelasan dan konsistensi dalam menjalankan suatu kebijakan dari pelaksana (implementor) kebijakan. Sumber-sumber yang akan mendukung kebijakan yang efektif terdiri dari

1) Sumber Daya Manusia

2) Sumber Daya Kewenangan

3) Sumber Daya Informasi

4) Sumber Daya Sarana dan Prasarana

c. Disposisi

Menurut Edward III dalam Widodo (2010:104) disposisi dikatakan sebagai "kemauan, keinginan dan kecenderungan para pelaku kebijakan untuk melaksanakan kebijakan secara sungguhsungguh sehingga apa yang menjadi tujuan kebijakan dapat diwujudkan. Faktor-faktor yang menjadi perhatian Edward III dalam Agustinus (2006:159) mengenai disposisi terdiri dari :

1) Pengangkatan Birokrasi.

2) Insentif

d. Struktur Birokrasi

Menurut Edward III dalam Widodo (2010:106) menyatakan bahwa "implementasi kebijakan bisa jadi masih belum efektif karena ketidak efisienan struktur birokrasi”. Terdapat dua karakteristik utama dari birokrasi yakni:

1) Standar Operational Procedure (SOP)

2) Fragmentasi

\section{Pengelolaan Sampah}

Sampah didefinisikan sebagai suatu benda yang tidak digunakan atau tidak dikehendaki dan harus dibuang, yang dihasilkan dari kegiatan manusia (Manik, 2009:67).

Sementara Undang-Undang Nomor 18 Tahun 2008 Pasal 1 tentang Pengelolaan Sampah disebutkan sampah adalah kegiatan sehari-hari manusia atau proses alam yang berbentuk padat atau semi padat berupa zat organik atau anorganik bersifat dapat terurai atau tidak dapat terurai yang di anggap sudah tidak berguna lagi dan dibuang ke lingkungan, (Slamet,2002:15) . 
Pengelolaan Sampah merupakan kegiatan yang sistemasis, menyeluruh dan berkesinambungan meliputi pengurangan dan penangan sampah (UU Nomor 18 Tahun 2008).Terdapat 2 kelompok utama pengelolaan sampah yaitu:

1) Pengurangan Sampah

2) Penanganan Sampah

Suwerda (2012:86) mengemukakan beberapa dampak apabila sampah tidak dikelola dengan baik sebagai berikut:

a. Sampah dapat menjadi sumber penyakit,lingkungan menjadi kotor. Hal ini akan menjadi tempat yang subur bagi mikroorganisne patogen yang berbahaya bagi kesehatan manusia, dan juga menjadi tempat sarang lalat, dan hewan liar lainnya.

b. Pembakaran Sampah dapat berakibat terjadinya pencemaran udara yang dapat menggangu kesehatan masyarakat, dan memicu terjadinya pemansan global.

c. Pembusukan sampah dapat menimbulkan bau yang tidak sedap dan berbahaya bagi kesehatan. Cairan yang dikeluarkan dapat meresap ketanah dan dapat menimbulkan pencemaran sumur, air tanah dan yang dibuang kebadan air akan mencemari sungai.

d. Pembuangan sampah kesungai atau badan air dapat menimbulkan pendangkalan sungai, sehingga dapat memicu terjadinya banjir.

\section{Metodologi Penelitian}

Adapun penelitian ini menggunakan penelitian kualitatif dengan pendekatan deskriptif analisis, karena persoalannya sangat komprehensif, mendalam dan sangat luas.Pengumpulan data dilakukan dengan observasi, wawancara dan dokumentasi

\section{Hasil Penelitian}

Dalam melaksanakan Implementasi Kebijakan mempunyai kriteria yang berbeda menurut teori George Edward yaitu: Komunikasi, Sumber daya, Disposisi dan Struktur Birokrasi.

Dinas Lingkungan Hidup Kota Lhokseumawe telah berusaha melakukan berbagai cara, salah satunya dengan turun tangan langsung kelapangan secara konsisten setiap bulannya untuk melihat kinerja petugas dan fasiltas yang masih kurang dalam pengelolaan sampah.

Sumber daya mempunyai peranan penting dalam implemnetasi kebijakan, pada kenyatannya masih adanya kendaraan yang digunakan untuk membawa sampah ke TPA sudah tidak layak digunakan lagi, karena sudah banyaknya bak kotainer atau truk untuk penampungan sampah yang bolong atau rusak. 
Indikator implemetasi selanjutnya adalah disposisi Birokrasi di Dinas Lingkungann Hidup Kota Lhokseumawe sebagian besar sudah bekerja dan di tempatkan pada posisi yang sesuai dengan riwayat pendidikan, sehingga pekerjaan yang diamanahkan kepadanya dapat terlaksana sesuai dengan yang diharapkan.Akan tetapi masih kurangnya perhatian pemerintah kepada petugas lapangan pengelola sampah hal itu dapat dilihat dari tidak adanya insentif untuk petugas lapangan pengelola sampah.

Birokrasi merupakan salah satu unsur dalam implementasi kebijkan, Birokrasi baik secara sadar maupun tidak sadar memilih bentuk-bentuk organisasi untuk kesepakatan kolektif dalam rangka memecahkan masalah sosial dalam kehidupan modern yang terkadang sengaja dibentuk untuk menjalankan suatu kebijakan tertentu.

Fakta yang terlihat bahwa masih belum adanya SOP yang jelas dari Dinas Lingkungan Hidup yang mengatur tentang tugas dan sistem kerja petugas lapangan di TPA Alue Lim, sehingga petugas hanya mengerjakan pekerjaan pada waktu tertentu saja tanpa adanya pengawasan. Dinas Lingkungan Hidup Kota Lhomseumawe sudah melakukan beberapa kerja sama dan koordinasi dengan beberapa instansi dianataranya kerja sama dengan PLN dan Dinas pekerjaan umum, dengan harapan agar semua program yang sudah di rencanakan bisa berjalan dengan maksimal dan tercapainya tujuan yang diinginkan.

Adapun hambatan dalam pelaksaan Implementasi Kebijakan Qanun pengelolaan sampah oleh Dinas Lingkungann Hidup Kota Lhokseumawe ada dua yakni, adanya aspek internal yang kurang mencukupi dalam pelaksanaan program pengelolaan sampah, serta adanya aspek eksternal yang sangat mempengaruhi sehingga belum terlaksananya Kebijakan dalam pengelolaan sampah oleh Dinas Lingkungan Kota Lhokseumawe.

Dan masih kurangnya perhatian pemerintah terhadap para petugas lapangan pengelola sampah, karena semenjak 2 tahun terakhir tidak ada lagi fasilitas perlengkapan kerja yang diberikan kepada petugas, baik itu seragam kerja maupun perlengkapan lainnya yang mendorong petugas lapangan pengelola sampah untuk lebih semangat dalam bekerja.

Faktor eksternal juga sangat mempengaruhi pelaksanaan program pengelolaan sampah, Dinas Lingkungan Hidup telah menyediakan fasilitas untuk mendorong kegiatan pengelolaan sampah dan melakukan berbagai cara agar terlaksananya program pengelolaan sampah. Namun masih ada beberapa faktor yang menyebabkan kurang terlaksananya program tersebut dengan baik.

Salah satu cara yang dilakukan pemerintah untuk mengelola sampah di Kota Lhokseumawe adalah dengan menyediakan tempat pengumpulan sampah sementara di beberapa tempat di Kota Lhokseumawe, namun dalam penempatan TPS harus adanya izin dari pemerintah gampong. Kendala yang dihadapi oleh Dinas Lingkungan Hidup Kota Lhokseumawe yaitu tidak adanya izin dari masyarakat di beberapa Gampong di Kota Lhokseumawe untuk penempatan TPS di daerah tersebut, 
dengan berbagai alasan salah satunya mengganggu pernafasan dan mecemari udara .

Dan juga kendala yang dihadapi pemerintah yaitu banyaknya masyarakat yang mengganggap sepelemasalah sampah dan tidak ikut berpartisipasi untuk mengelola sampah. Karena salah satu cara pengelolaan sampah sebaiknya selain pemerintah yang mengupayakan segala macam program untuk menanggulangi sampah dan menjadikan sampah sumber daya yang bernilai ekonomi, juga diperlukannya kesadaran penuh dari masyarakat untuk membuang sampah pada tempat yang telah disediakan pemerintah agar terciptanya lingkungan yang bersih dan sehat di Kota Lhokseumawe.

\section{Kesimpulan}

Berdasarakan hasil penelitian tersebut di atas, maka dapat disimpulkan sebagai berikut:

1. Implementasi Kebijakan Qanun Kota Lhokseumawe Nomor 9 Tahun 2015 Tentang Pengelolaan Sampah Oleh Dinas Lingkungan Hidup Kota Lhokseumawebelum terlaksana secara optimal, karena; (a) Komunikasi, belum adanya sosialisasi langsung dari pemerintah kepada masyarakat mengenai pengelolaan sampah dan larangan membuang sampah di sembarangan tempat. (b)Sumber Daya, Fakta yang terlihat masih kurangnya perhatian pemerintah terhadap (c)Disposisi, Faktanya Birokrasi di Dinas Lingkungann Hidup Kota Lhokseumawe sebagian besar sudah bekerja dan di tempatkan pada posisi yang sesuai dengan The right man in the right place, sehingga pekerjaan yang diamanahkan kepadanya dapat terlaksana sesuai dengan yang diharapkan dan, (d)Struktur Birokrasi, Fakta yang terlihat bahwa masih belum adanya SOP yang jelas dari Dinas Lingkungan Hidup yang mengatur tentang tugas dan sistem kerja petugas lapangan di TPA Alue Lim.

2. Hambatan yang terjadi dalam pelaksanaan Implementasi Kebijakan Qanun Kota Lhokseumawe Nomor 9 Tahun 2015 Tentang Pengelolaan Sampah Oleh Dinas Lingkungan Hidup Kota Lhokseumawediantaranya: masih kurangnya sarana dan prasarana yang dimiliki Dinas Lingkungan Hidup Kota Lhokseumawe untuk mengelola sampah, baik itu berupa armada pengangkut sampah maupun perlengkapan yang dibutuhkan petugas untuk mengumpulkan sampah Dan tidak bisa berfungsinya mesin pengelolaan sampah sampah, karena tidak sesuai dengan aspek yang dibutuhkan, sehingga sampah hanya dibiarkan bertumpuk setiap harinya. dan juga masih kurangnya kesadaran maupun pastisipasi dari masyarakat untuk mengelola sampah dan membuang sampah pada tempat yang telah disediakan oleh pemerintah.

\section{Daftar Pustaka}

Abidin, Said Zainal. 2004. Kebijakan Publik. Jakarta: Pancar Siwah 
Agustinus, leo. 2006. Politik dan Kebijakan Publik. Bandung : AIPI

Iskandar.2009. Metode Penelitian Kualitatif.Jakarta : Gaung Persada (GP Press).

Kencana, Inu Syafiie.2013. Sistem Administrasi Negara. Jakarta : PT.Bumi Aksara.

Moleong, Lexy J .2001.Metode Penelitian Kualitatif. Bandung: Remaja Rosdakarya.

Nugroho, Riant. 2011. Public Policy. Jakarta: PT Elex Media Komputindo.

Slamet,Juli Soemirat. 2002. Kesehatan Lingkungan. Yogyakarta :Gajah Mada University Press

Subarsono.AG. 2005. Analisis Kebijakan Publik. Yogyakarta: Pustaka Pelajar

Sudrajat. 2009. Mengelolah Sampah Kota. Jakarta :Penebar Swadaya

Sugiyono. 2002. Metode Penelitian Administrasi. Bandung : CV. Alfabeta

Bandung: Alfabeta

Sumantri A. 2010. Kesehatan Lingkungan. Jakarta: Kencana Prenada Media Group

Tangkilisan, Hessel Nogi S. 2003.Evaluasi Kebijakan Publik.Yogyakarta. Balairung

Toha, Miftah. 2008. Ilmu Administrasi Publik Kontemporer. Jakarta: Kencana.

Wahab, Solichin Abdul. 2002. Analisis Kebijakan dari Formulasi ke Implementasi Kebijakan.Jakarta: PT. sBumi Aksara

Widiatmomoko dan sititorini Moerdjoko. 2002. Pemindahan dan Pemilihan Sampah. Jakarta: Gajah Mada

Widodo, Joko. 2008. Analisis Kebijakan Publik. Jakarta. Bayumedia

Winarni, Budi. 2007. Teori Kebijakan Publik dan Proses Edisi Revisi. Yokyakarta: Media Presido

Qanun Kota Lhokseumawe Nomor 09 Tahun 2015 Tentang Pengelolaan Sampah 